\title{
Quantitative Analysis of Medication Management and Use in Bima Regional Public Hospital
}

\author{
Sirajudin1, A. Adji Prayitno Setiadi2,3*, Yosi Irawati Wibowo2,3, Eko Setiawan²,3 \\ 1) Master of Pharmacy Program, Faculty of Pharmacy, Surabaya University, Surabaya, Indonesia \\ 2) Center for Medicine Information and Pharmaceutical Care (CMIPC), Faculty of Pharmacy, Surabaya University, \\ Surabaya, Indonesia \\ 3) Clinical and Community Pharmacy Department, Faculty of Pharmacy, Surabaya University, Surabaya, Indonesia
}

adji ps@staff.ubaya.ac.id

DOI: http://doi.org/10.29080/jhsp.v5i1.390

Received : Juni 2020, Accepted : Januari 2021, Published : April 2021

\section{Keywords}

medication management; medication use; hospital

\begin{abstract}
The large number of medications circulating in hospitals may increase the risks of mismanagement of pharmaceutical inventory; hence studies on the management and use of medication are needed. This present study aims to analyse medication management and use in Bima Regional Public Hospital. This is a retrospective observational study, using descriptive data analysis. The analysis of medication management was conducted for the planning, procurement, storage and distribution stages; while the evaluation of medication use was done on antibiotic injections commonly prescribed using DDD/100 patient-days. The results showed that in the planning stage, three medications were in the $A V$ category (i.e. Lactated Ringer's Infusion, Fentanyl and Tetagam Inj.); one vital medication was in the BV category (i.e. anti-snake venom serum); and nine medications were in the CV category (i.e. Aminophylline Inj. 24mg, Anti-Tetanus Serum 1500 IU, Phenobarbital Inj., Levosol Inj., Magnesium Sulphate Inj. 20\%, Norepinephrine Inj., OTSU D40 Infusion, OTSU MgSO4-40 Inj., Pethidine Inj. $50 \mathrm{mg} / \mathrm{ml}$. The conformity of procurement funding was $107.3 \%$, while the accuracy of procurement process (medication purchased/prescribed) was 275\%; and there were two damaged products during storage (0.476 \%). The evaluation of medication use for 12 antibiotic injections found a total 45.44 DDD/100 patient-days. The findings in this study provides a baseline data in optimising future practices of medication management and use in hospitals, especially in Bima Regional Public Hospital.
\end{abstract}

\section{Introduction}

The implementation of national health coverage (Jaminan Kesehatan Nasional, JKN) by Indonesian Government demands proper medication management to optimise the use of healthcare funding without sacrificing the quality of healthcare services provided to patients. The cycle of medication management consists of four stages, i.e., selection, procurement, storage, and distribution(1). Meanwhile, the Joint Commission has established seven critical points of medication management in hospitals, including planning, selection and procurement, storage, ordering, preparing and administration, monitoring, and evaluation. These critical points correlate to one another, which requires each to be properly managed to ensure the optimal use of medication and patient safety.

High volumes of unused and expired medications are examples of medication mismanagement that may contribute to inefficient healthcare spending $(2,3)$. In addition to the inefficient spending, the failure to ensure procurement of essential medications is another parameter of medication mismanagement that may hamper the quality of healthcare services (4). Another cause of the increasing healthcare costs is irresponsible use of medication, which may lead to the increase risk of patients' morbidity or even mortality (5-7). Unlike other categories of medications, the irresponsible use of antibiotics not only has adverse consequences on the individual patients, but also to the larger community-as it increases the risk of antibiotic resistance $(8,9)$. Infections caused by antibiotic-resistant bacteria can spread to the larger 
community when proper measurements are not taken(10-12).

Hospitals, as the main providers of secondary and tertiary care, have seen medication as one of the most essential assets to ensure quality and continuity of health services. However, published research, including those in Indonesia, has shown that there is a great need to optimise the management and use of medication(13-16). Antibiotic is one of medication categories that require urgent interventions to optimise its use, particularly in hospital settings(13-16). Admittedly, there are several barriers to quality management and use of medications one of which is the development of new medications(17). Hence, Medicines Management teams in hospitals should always take into consideration the potential new medications, including antibiotics, which is about to be introduced in Indonesian market(18).

Up to now, few articles has been published on the management and use of medications in Indonesian hospital settings. There was one study conducted in Prof. Dr. R. D. Kandou Regional Hospital in Manado, North Sulawesi, using ABC-VEN analysis. The findings showed six cardiovascular medicines and anesthetics in the A category (20\%) with an absorption of Rp. 342,470,000 (70\%) of the funding, and five medications were categorized as $\mathrm{V}$ (vital), for example furosemide injection. There were some medications in the AV category that were lacking in procurement, thus indicating the inefficiency in planning and procurement of medications in this hospital (19).

Bima Regional Public Hospital is a type C public hospital, which is the main healthcare provider for the city of Bima, West Nusa Tenggara. This is the only hospital serving more than 400,000 residents from 18 sub-districts in Bima(20). Since 2014, the hospital has been transformed into Badan Layanan Umum Daerah (BLUD)(21); BLUD is a unit of Satuan Kerja Perangkat Daerah (SKPD) under the supervision of the regional government - which implements a certain Pola Pengelolaan Keuangan ( $P$ PK), and aims to provide goods and/or services not for profits (22). One of the responsibilities of the Pharmacy Installation in hospitals, as stated in the Regulation of the Ministry of Health number 72 of 2016 about Pharmaceutical Service Standards in Hospitals, is to develop policies to optimise the management and use of medications as well as to provide quantitative data on medication use. This present study aims to conduct a quantitative analysis on the medication management and use in Bima Regional Public Hospital, particularly with regards to antibiotic injections.

\section{Methods}

This is an observational study using retrospective data obtained from the Pharmacy Installation of Bima Regional Public Hospital in 2016. The data included all medical records and medication management records during 2016. Descriptive analysis was used to summarise the data.

\section{Analysis of Medication Management}

Medication management in this study consisted of several stages, including planning, procurement, storage, and distribution. The following indicators were used to analyse each stage of the medication management:

\section{Planning}

The Pareto ABC-VEN was used to evaluate the medication inventory planning. Through $A B C$ classification, a medication is considered in the A category if it absorbs $70 \%$ of the total medication budget, in the B category if it absorbs $20 \%$ of the total budget, and in the C category if it absorbs $10 \%$ of the total budget. Meanwhile, the VEN classification categorizes medicines into Vital, Essential, and Non-Essential. When combined, the ABC-VEN matrix would provide information whether the budget is efficiently allocated for drugs with higher priority.

2. Procurement

The indicators to analyse the procurement stage included:

a. Conformity of procurement funding

$\begin{aligned} & \text { Conformity of } \\ & \text { Procurement } \\ & \text { Funding }\end{aligned}$
Fundal Funds Provided for Medication Procurement $\quad X \quad 100 \%$

b. Conformity of procurement process

$\begin{aligned} & \text { Conformity of } \\ & \text { Procurement Process }\end{aligned}=\frac{\text { Total of Medications Purchased }}{\text { Total of Medications Prescribed }} \times 100 \%$


3. Storage

The indicators to analyse the storage stage included:

a. Percentage of damaged medications

$\begin{aligned} & \text { Percentage of } \\ & \text { Damaged } \\ & \text { Medications }\end{aligned}$
Motal of Available Medications $\quad 100 \%$

b. Value of damaged medications

Value of Damaged Medications $\quad=$ Number of Damaged Medications $\quad X \quad$ Price per Unit

4. Distribution

The indicators to analyse the distribution stage included:

a. Cost of medication per visit

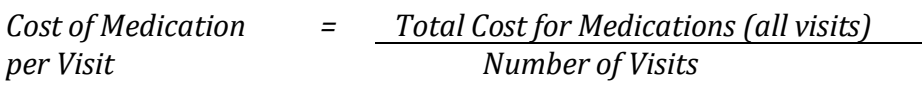

b. Cost of medication per prescription

Cost of Medication $=\quad$ Total Cost for Medications (all prescriptions)

per Prescription Number of Presciptions

\section{Analysis of Medication Use}

For the purposes of this research, medication use evaluation focused on 12 types of the most widely used antibiotic injections in the hospital. The data was derived from antibiotics use records in the inpatient setting. The total medication use is expressed in DDD/100 patient-days. The Defined Daily Doses (DDD) referred to the average of antibiotic dosage used on adults, regardless of the indications. The DDD reference (in grams) can be found in the ATC/DDD index guidelines published by the World Health Organisation (WHO)(23).

$$
\text { DDD } / 100 \text { patient-days }=\frac{\text { Amount (grams) of AB used per patient }}{\text { WHO DDD standard in grams }} \times \frac{100}{\text { Total LOS }}
$$

Note: ATC=Anatomical Therapeutic Chemical Classification; DDD=defined daily doses; LOS=length of stay.

\section{Results}

Analysis of Medication Management

Findings from the analysis of medication management in the planning, procurement, storage, and distribution stages are described as follows:

\section{Planning}

The analysis on the classification of medications using the ABC method in Bima Regional Public Hospital indicated that there were 43 medications in the A category. Further analysis involving VEN classification indicated that of the 43 medications in the A category; of those, three could be classified as $\mathrm{V}$ (Vital), including:

1. Lactated Ringer's Infusion, indicated for restoring electrolytes imbalance in the case of dehydration. This medication is widely and commonly used in hospital inpatient settings.

2. Fentanyl Injection, indicated as one of the anaesthesia administered for patients undergoing surgery.

3. Tetagam Injection, indicated for Tetanus Immune Globulin (TIG) treatment in the management of tetanus cases, as a preventative measure for treating wounds at risk for tetanus infections and for those with incomplete tetanus vaccination records.

There were 68 medications in the B category, one of which was also classified as V (Vital), which was the anti-snake venom serum. Meanwhile, 275 medications were classified in the C category; nine of which were also classified as $\mathrm{V}$ (Vital), including:

1. Aminophylline Injection $24 \mathrm{mg}$, indicated for bronchial and cardiac asthma, coronary artery spasm, and respiratory depression. Aminophylline injection was categorised as vital medication, taking into 
account that asthma is one of the top ten most commonly treated diseases treated in Bima Regional Public Hospital

2. Anti-Tetanus Serum 1500 IU, indicated for tetanus prevention caused by Clostridium tetani bacteria. It is vital to administer anti-tetanus medication in patient with open wounds, especially those unable to recall their tetanus vaccination records.

3. Phenobarbital Injection, indicated for controlling and reducing seizures. Anti-seizure medication is vital as an effort to prevent injuries, and to allow patients to carry on with their normal activities.

4. Levosol Injection, indicated to increase blood pressure for cases of acute hypotension.

5. Magnesium Sulfate Infusion 20\%, indicated for eclampsia seizures and to treat Torsades de Pointes, a type of heart rhythm problems (heart arrhythmias). Magnesium Sulfate works by replacing body's Magnesium and increasing water content in the intestine.

6. Norepinephrine Injection, indicated for potentially life-threatening severe hypotension. This condition is commonly referred to as shock, which may cause a sharp decrease in organ functions, and even multiple organ failures. In a condition of shock, particularly caused by sepsis, norepinephrine is administered to maintain regular blood flow to body's organs.

7. OTSU D-40 Infusion, indicated for various conditions, one of which is in the vital treatment of hypoglycaemia. Without appropriate and timely intervention, hypoglycaemia has the potential to cause brain damage due to extremely reduced energy intake for brain function. As a consequence of brain damage, other body's functions may also be adversely affected.

8. OTSU MgSO4-40 Injection, indicated to prevent and treat eclampsia seizures and to treat Torsades de Pointes. This medication is categorised as vital because hypertension crisis is a clinical diagnosis, such that the patient's the clinical condition is considered to be more important than the absolute value of blood pressure. Such critical condition requires immediate treatment to prevent further organ damage.

9. Pethidine Injection $50 \mathrm{mg} / \mathrm{ml}$, indicated for pain relief. Typically, this medication is administered for patients undergoing surgery to mitigate post-surgical pain and discomfort.

\section{Procurement}

The indicators used to analyse the procurement stage included the conformity of procurement fund utilisation and the percentage of appropriate procurement process. The following calculation expressed the conformity of procurement fund utilisation in Bima Regional Public Hospital in 2016:

Conformity of procurement funding

$$
\begin{aligned}
& =\frac{\text { Rp. 7,432,181,780 }}{\text { Rp. 6,927,082,054 }} \times 100 \% \\
& =107 \cdot 3 \%
\end{aligned}
$$

Meanwhile, conformity of the procurement process was determined at $275 \%$.

\section{Storage}

The analytical indicators for the storage stage included the percentage and value of damaged medications. The following calculation indicated the percentage of damaged drugs in Bima Regional Public Hospital in 2016:

Percentage of damaged medications

$$
\begin{aligned}
& =\frac{2}{420} \times 100 \% \\
& =0.476 \%
\end{aligned}
$$

Meanwhile, the calculation of damaged medication value can be seen in Table 1.

Table 1. Value of Damaged Medications in Bima Regional Public Hospital in 2016

\begin{tabular}{lllll}
\hline Drug Name & $\begin{array}{l}\text { Dosage } \\
\text { Form }\end{array}$ & Amount & Price (Rp) & Value (Rp) \\
\hline Isotic Neolysin & Eye drop & 3 & 24,750 & 74,250 \\
Tyamin (B1) 50mg & Tablet & 128 & 79 & 10,112 \\
\hline Value of Damaged Medications & & & $\mathbf{8 4 , 3 6 2}$ \\
\hline
\end{tabular}




\section{Distribution}

The indicators for analysis in the distribution stage included the cost of medication per visit and cost of medication per prescription, for which the cost calculations in the Bima Regional Public Hospital in 2016 were as follows:

$\begin{array}{ll}\text { Cost of medication per prescription } & =\frac{\text { Rp. } 6,320,835,907}{115 \cdot 613} \\ & =\text { Rp. } 54,672 \\ \text { Cost of medication per visit } & =\frac{\text { Rp. } 6,186,010,475}{72,205} \\ & =\text { Rp. } 85,670\end{array}$

Summary of the evaluation of medication management in Bima Regional Public Hospital in 2016 from planning, procurement, storage, to the distribution stages is depicted in Table 3.

Tabel 3. Evaluation Summary of Medication Management

\begin{tabular}{lc}
\multicolumn{1}{c}{ Indicators } & Findings \\
\hline Procurement: & \\
Conformity of Procurement Process & $275.0 \%$ \\
Conformity of Procurement Funding & $107.3 \%$ \\
Storage: & \\
Percentage of Damaged Medications & $0.476 \%$ \\
Value of Damaged Medications & Rp. 84,362 \\
Distribution & \\
Cost of Medication per Visit (available) & \\
Cost of Medication per Visit & Rp. 102,929 \\
Cost of Medication per Prescription (available) & Rp. 85,670 \\
Cost of Medication per Prescription & Rp. 64,285 \\
\hline
\end{tabular}

\section{Analysis of Medication Use}

Quantitative analysis was conducted using DDD/100 patient-days calculations. The DDD/100 patient-days for 12 antibiotic injections use in Bima Regional Public Hospital in 2016 for a total of Length of Stay (LOS) of 49,094 hospitalisation days can be seen in Table 4.

Tabel 4. DDD/100 Patient Days in Bima Regional Public Hospital (2016)

\begin{tabular}{|c|c|c|c|c|c|}
\hline Type of AB & ATC & Unit/g & $\begin{array}{l}\text { DDD } \\
\text { WHO }\end{array}$ & $\begin{array}{c}\text { Total AB } \\
\text { used }\end{array}$ & $\begin{array}{c}\text { DDD } 100 \\
\text { patient-days }\end{array}$ \\
\hline Ceftriaxone Inj & J01DD04 & 1 & 2 & 21,263 & 21.66 \\
\hline Cefotaxime Inj $1 \mathrm{~g}$ & J01DD01 & 1 & 4 & 36,834 & 18.76 \\
\hline Cefazolin Inj & J01DB04 & 1 & 3 & 2,880 & 1.96 \\
\hline Levofloxacin IV $500 \mathrm{mg}$ & J01MA12 & 0.5 & 0.5 & 657 & 1.34 \\
\hline Gentamicin Inj 40 mg & J01GB03 & 0.04 & 0.24 & 1,873 & 0.64 \\
\hline Meropenem Inj $1 \mathrm{~g}$ & J01DH02 & 0.2 & 2 & 2,626 & 0.53 \\
\hline Ceftazidime Inj & J01DD02 & 1 & 4 & 377 & 0.19 \\
\hline Cefoperazone Sulbactam Inj & J01DD62 & 0.5 & 4 & 751 & 0.19 \\
\hline Ampicillin Inj & J01CA01 & 1 & 2 & 100 & 0.10 \\
\hline Amikasin Inj 500 mg & J01GB06 & 0.5 & 1 & 80 & 0.08 \\
\hline Cefepime Inj $1 \mathrm{~g}$ & J01DE01 & 1 & 2 & 1 & 0.00 \\
\hline Vincristin Inj & J01CA02 & $\mathrm{n} / \mathrm{a}$ & $\mathrm{n} / \mathrm{a}$ & 3 & - \\
\hline \multicolumn{2}{|c|}{ TOTAL } & & & & 45.44 \\
\hline
\end{tabular}

Note: $\mathrm{AB}=$ antibiotics; IV=intravenous; DDD WHO = DDD standard based on $A T C / D D D$ index from WHO (in grams); n/a=not applicable 
The most commonly prescribed antibiotic was Ceftriaxone Injection $1 \mathrm{~g}$ in the amount of 21,263 vials, and Cefotaxime Injection $1 \mathrm{~g}$ in the amount of 36,834 vials. In addition, based on DDD/100 patientdays calculations, two of the most common antibiotic injections were Ceftriaxone Injection $1 \mathrm{~g}$, averaging 21.66 DDD/100 patient-days; and Cefotaxime Injection 1g with an average of 18.76 DDD/100 patient-days. The findings also indicated that the total of antibiotic use reached 45.44 DDD/100 patient-days, which indicated that the total use of antibiotic injections for each patient is 0.45 times compared to the WHO standard.

\section{Discussion}

The analysis of medication management in Bima Regional Public Hospital was conducted for all stages of management, from planning to distribution. Using ABC-VEN analysis for the planning stage, the study found three types of drugs in the A-V matrix (i.e., Lactated Ringer's Infusion, Fentanyl Injection, and Tetagam Injection). Medications in the A-V matrix are categorised as vital based on the critical status, and have high frequency of use(24). As such, the hospital must ensure that these medications are continuously available in its inventory for cases of emergency. Meanwhile, the medications in the B-V Matrix are considered moderately vital in medical care and should be stored in larger quantities(24). There was one drug in this study categorized in the B-V Matrix, which is the anti-snake venom serum. The serum is administered to patients suspected or confirmed to have been bitten by venomous snake and have shown one or more clinical signs of snake bite. Snake bite cases in Bima often occur in the rainy season, during which farmers are planting seeds in the fields. Consequently, the supply of this serum has to be controlled and be readily available in the related season. The $\mathrm{C}-\mathrm{V}$ Matrix included medications with low stock value, but must always be made available(24). There are nine medications in the $\mathrm{C}-\mathrm{V}$ Matrix category, i.e., Aminophylline Injection, Anti-Tetanus Serum 1500 IU, Phenobarbital Injection, Levosol Injection, Magnesium Sulfate Infusion 20\%, Norepinephrine Injection, OTSU D-40 Infusion, OTSU MgSO4-40 Injection, and Pethidine Injection $50 \mathrm{mg} / \mathrm{ml}$.

The medication inventory planning in Bima Regional Public Hospital has been based on the total medication use in previous period plus 10-20\% buffer stock. In addition, the hospital also considers physicians' recommendations in the planning of pharmaceutical purchasing. Most medications in the Pharmacy Installation of Bima Regional Public Hospital are generic drugs. Purchasing of brand-name drugs are only reserved for medicines with do not have their generic equivalents(22). Nevertheless, there were still several issues for which improvements are deemed necessary, in terms of the system or criteria to be used to select medications in the hospital. Such system or criteria should be developed by considering the available fund in the hospital. All medications required in the hospital should be checked whether they are listed in the National Formulation and e-catalogue(25). When the required medications are not listed in the National Formulation, their procurement would be based on the policies enacted by the Hospital Director.

With regards to procurement of medications, the funds provided in Bima Regional Public Hospital for the 2016 was Rp. 7,432,181,780, which was greater than the amount of actual funds utilised for medication procurement, which was Rp. 6,927,082,054. Therefore, the conformity of medication procurement funding was $107.3 \%$. The higher funds available is due to the availability of support funding from the hospital in the form of General Funds Allocation and funding from the National Health Coverage $(\mathrm{JKN})^{(22)}$. The accuracy of medication procurement process averaged at $275 \%$. The value higher than $100 \%$ could have occured due to the higher number of medications purchased than the medications prescribed. Several medications made available in high quantities but had low usage included ISDN, Analsic, Gemfibrozil, Kidmin Infusion, Aminophylline Injection, Levosol Injection, Haloperidol $1.5 \mathrm{mg}, \mathrm{NaCl}$ 3\%, Valisanbe $5 \mathrm{mg}$, Merlopam $2 \mathrm{mg}$, Glyceryl Guaiacolate, Adalat Oros, Cetadop Injection, and Ofloxacin $400 \mathrm{mg}$.

Further research is required to understand the underlying factors that have caused the oversupply of medications beyond the hospital's actual needs. One of the factors hypothesised as the main cause is the high turnover in physician personnel, which may lead to the change in drug prescription patterns. In other words, the medications previously used by a certain group of physicians could change into low-demand medications once the physicians were no longer placed in Bima Regional Public Hospital. The use of stock cards, accuracy of data on the stock cards, and the match between procurement and medication needs are potential solutions to minimise waste due to dead stock ${ }^{(26)}$. Monitoring and evaluation must be conducted according to certain procedures. Bima Regional Public Hospital could initially establish a Pharmacy and Therapeutic Committee. Then, evaluation of medication management would become a joint responsibility among Pharmacy Installation, Pharmacy and Therapeutic Committee, and the hospital management board; the continous evaluation process should ensure medication management in the hospital is in compliance with the standards set by the Ministry of Health. 
In terms of medication storage, this study reported that the proportion of damaged drugs at Bima Regional Public Hospital in 2016 was $0.476 \%$ with the monetary value of Rp. 84,362. In other words, the burden caused by medication storage failure in Bima Regional Public Hospital could be categorised as extremely low. However, further research on the suitability of storage conditions as mandated by the Minister of Health regulation number 72 of 2016 is needed(27). For instance, the suitability of storage condition in the Bima Regional Public Hospital medication storage facility compared to the First Expired First Out (FEFO), First In First Out (FIFO), and Look Alike Sound Alike (LASA) storage principles warrants further investigations. In addition, Bima Regional Public Hospital has limited human resources to handle medications being delivered from Pedagang Besar Farmasi (PBF). The medications had to be checked by the receiving unit before they could be stored in the storage unit. The unit should check for several things, including: the type of drugs, number of medications, and the expired dates; they are also required to check the completeness of the invoice.

The distribution of medications or prescription services in the Pharmacy Installation of Bima Regional Public Hospital have been provided for both inpatients and outpatients, as well as to support the hospital's medical services. The medication expenditure allocated by Bima Regional Public Hospital in 2016 was Rp. 102,929 per visit (derived from calculating available funds for medications divided by the number of visits). Meanwhile, the actual cost of medication per visit was Rp. 85,670. In terms of cost per prescription Bima Regional Public Hospital allocated Rp 64,285 per prescription in 2016 (derived from the available funds for medications divided by the number of prescriptions), while the actual value of medication cost was 54.672 per prescription. Judging from the figures, the distribution of medications in Bima Regional Public Hospital could be considered as efficient as the costs did not exceed the allocated expense budget.

In Bima Hospital, medications for outpatients were given for three to seven days of therapy, while medications for inpatients were given on a three-day count (floor stock system). In the outpatient setting, there is a possibility of patients do not use their medications, which could cause ineffective spending and waste in healthcare. To anticipate that, hospital management would be required to develop a policy or system on how to return unused medications. This policy should be followed up by the Pharmacy Installation staff by communicating such system to the patients and their families. In the inpatient setting, Unit Dose Dispensing (UDD) system might help to effectively distribute medications to patients, hence reducing the risks of wasteful spending in which the cost of distributed medications exceeds the true cost of medications needed or used. This UDD system is also recommended to be implemented in the hospitals, as suggested in the Minister of Health regulation number 72 of $2016^{(27)}$. One of the advantages of the UDD system compared to the floor stock system is that it minimise the rate of medication errors.

This study reported that the most prescribed antibiotics was Ceftriaxone Injection $1 \mathrm{~g}$ in the amount of 21,263 vials, and Cefotaxime Injection $1 \mathrm{~g}$ in the amount of 36,834 vials. Based on DDD/100 patient-days calculation, two most common antibiotic injections Ceftriaxone Injection $1 \mathrm{~g}$, averaging 21.66 DDD/100 patient-days, and Cefotaxime Injection $1 \mathrm{~g}$ with an average of $18.76 \mathrm{DDD} / 100$ patient-days. The high use of ceftriaxone in this study is in line with previously published studies(28). One of the condiserations of using ceftriaxone is its wide spectrum of antibacterial property, which makes it the primary choice for empirical antibiotics therapy(29). Nevertheless, the use of ceftriaxone should be given special care by healthcare professionals as it may cause unknown serious adverse drug reactions, such as anaphylactic reactions, and increase the risk of infections caused by Extended-Spectrum Beta Lactamasess (ESBL) producing bacteria(30-32). The use of antibiotics considered as the 'last-resort', such as meropenem, was fairly low in this study. This could be seen as a positive tendency, since the lesser the last-resort antibiotics used, the lower the risk of drug resistance. Hence, meropenem can be used to treat infections caused by bacteria that have developed resistance on one or more types of antibiotics $(33,34)$.

\section{Conclusion}

This study provided insight on the medication management in Bima Regional Public Hospital. The analysis in the planning stage reported three types of medications which were widely used and were classified as vital (i.e., Ringer Lactate Infusion, Fentanyl Injection, and Tetagam Injection); thus, the availability of these medications need to be guaranteed. The analysis of the procurement stage found that the conformity of funding utilisation was $107.3 \%$, and the conformity of medications purchased/prescribed was 275\%; this indicated the need to improve the procurement stage. From the storage stage analysis, the proportion of damaged medications was found to be $0.476 \%$ with the monetary value of Rp. 84,362, which is considered low. Meanwhile, the distribution stage could be considered as efficient in terms of the medication budget used, as the cost per visit and cost per prescription did not exceed the allocated funding. Although the use of medications, particularly antibiotics, have met the standard with regard to the quantities; the quality use of antibiotics in this hospital would require close monitoring. The high use of ceftriaxone warrants further considerations in order to optimise the benefit 
while reduce the risks. Findings from this study should provide a basis for future improvements in the medication management and use in Bima Regional Public Hospital.

\section{Acknowledgements}

The authors thank the entire staff and management of Bima Regional Public Hospital, West Nusa Tenggara Province, for all their support in this research.

\section{References}

1. Quick, J.D. Mananging Drug Supply the selection, procurement, distribution, and use of pharmaceuticals, 2nd ed. 1997.

2. $\quad$ Ebrahim, A. J., Teni, F. S., \& Yimenu D.K. Unused and Expired Medications: Are They a Threat? A Facility-Based Cross-Sectional Study. J Prim Care Community Health [Internet]. 2019;10. Available from: https://doi.org/10.1177/2150132719847857

3. Alnahas, F., Yeboah, P., Flidel, L., Albdin, A. Y., \& Alhareth K. Expired Medication: Societal, Regulatory and Ethical Aspects of a Wasted Oportunity. Int J Environ Res public Heal 17(3), 787. 2020;

4. Prinja, S., Bahuguna, P., Tripathy, J. P., \& Kumar R. Availability of medicines in public sector health facilities of two North Indian States. BMC Pharmacol Toxicol [Internet]. 2015;16(43). Available from: https://doi.org/10.1186/s40360-015-0043-8

5. Kshirsagar, N.A. Rational use of medicines: Cost consideration \& way forward Indian J Med Res [Internet]. 2016;144(4):502-5. Available from: https://doi.org/10.4103/0971-5916.200901

6. Ofori-Asenso, R., \& Agyeman, A. A. Irrational Use of Medicines-A Summary of Key Concepts. Pharm (Basel, Switzerland) [Internet]. 2016;4(4):35. Available from: https://doi.org/10.3390/pharmacy4040035

7. Beran, D., Ewen, M., Lipska, K., Hirsch, I. B., \& Yudkin JS. Availability and Affordability of Essential Medicines: Implications for Global Diabetes Treatment. Curr Diab Rep [Internet]. 2018;18(18):48. Available from: https://doi.org/10.1007/s11892-018-1019-z

8. Holmes, A. H., Moore, L. S., Sundsfjord, A., Steinbakk, M., Regmi, S., Karkey, A., Guerin, P. J., \& Piddock LJ. Understanding the mechanisms and drivers of antimicrobial resistance. Lancet (London, England) [Internet]. 2016;387(10014):176-87. Available from: https://doi.org/10.1016/S01406736(15)00473-0

9. Partridge, S. R., Kwong, S. M., Firth, N., \& Jensen, S. O. Mobile Genetic Elements Associated with Antimicrobial Resistance. Clin Microbiol Rev [Internet]. 2018;31(4). Available from: https://doi.org/10.1128/CMR.00088-17

10. Alam, M., \& Imran, M. No Title Screening and Potential of the Incidence of Resistance Tranfer Among the Multidrug and Heavy Metal Resistant Gram-Negative Isolates from Hospital Effluents of Northen India. Recent patents on anti-infective drug discovery, 13(2) [Internet]. 2018. 164-179 p. Available from: https://doi.org/10.2174/1574891X13666180702111330

11. Burcham, Z. M., Schmidt, C. J., Pechal, J. L., Brooks, C. P., Rosch, J. W., Benbow, M. E., \& Jordan, H. R. Detection of critical antibiotic resistance genes through routine microbiome surveillance. PLoS One [Internet]. 2019;14(3). Available from: https://doi.org/10.1371/journalpone.0213280

12. Christaki, E., Marcou, M., \& Tofarides, A. Antimicrobial Resistance in Bacteria: Mechanisms, Evolution, and Persistence. J Mol Evol [Internet]. 88(1):26-40. Available from: https://doi.org/10.1007/s00239-019-09914-3

13. Mao, W., Vu, H., Xie, Z., Chen, W., \& Tang, S. Systematic review on irrational use of medicines in China and Vietnam. PLoS One [Internet]. 2015;10(3). Available from: https://doi.org/10.1371/journalpone.0117710

14. Hidayat, F., Prayitno, A., \& Setiawan, E. Antibiotics Utilization Review in a Neonate Intensive Care Unit of a Public Hospital in Surabaya. Indones J Clin Pharm (IJCP), 8(1), 58-71. 2019;8(1):58-71.

15. Halim, S.V., Yulia, R., \& Setiawan, E. Carbapenem Utilization among Adults Inpatients in One Private Hospital in Surabaya. Indones J Clin Pharm. 2017;6(4):280-94.

16. Monica, S., Irawati, S., Setiawan E. Review of the Utilization, Conformity, and Cost of Antibiotics among Paediatric Inpatients in a Public Hospital in Surabaya. Indones J Clin Pharm. 2018;6(4):28094.

17. Masoud, A., Noori Hekmat, S., Dehnavieh, R., Haj-Akbari, N., Poursheikhali, A., \& Abdi, Z. An Investigation of Prescription Indicators and Trends Among General Practitioners and Specialists From 2005 to 2015 in Kerman, Iran. Int J Heal policy Manag [Internet]. 2018;7(9):818-827. Available from: https://doi.org/10.15171/ijhpm.2018.28

18. Halim, S.V., \& Setiawan, E. Seftarolin, Antibiotik Baru dengan Aktivitas Anti-MRSA: Sebuah Kajian Efektivitas, Keamanan, dan Biaya Penggunaan. J Farm Galen Galen J Pharm. 2020;6(1):160-80.

19. Martini, V., Citraningtyas, G., \& Yamlean, P. Evaluasi Perencanaan dan Pengadaan Obat di Instalasi 
Farmasi RSUP Prof. Dr. R.D. Kando Manado Berdasarkan Analisis ABC-VEN. Pharmacon J Ilm Farm UNSRAT. 2016;5(3):7-11.

20. Pemerintah Kabupaten Bima. Population and population growth rate by subdistrict in Bima Regency, 2010, 2014, and 2015 [Internet]. 2016; Available from: https://bimakab.bps.go.id/statictable/2016/07/21/165/jumlah-penduduk-dan-laju-pertumbuhanpenduduk-menurut-kecamatan-di-kabupaten-bima-2010-2014-dan-2015.html

21. Pemerintah Kabupaten Bima. Perbup No 34 Tahun 2013 Tentang Rencana Strategis Bisnis Pada Rumah Sakit Umum Daerah Bima. 2013;

22. Pemerintah Republik Indonesia. Perpres No 94 tahun 2007 tentang Pengendalian Dan Pengawasan Atas Pengadaan Dan Penyaluran Bahan Obat, Obat Spesifik Dan Alat Kesehatan Yang Berfungsi Sebagai Obat. 2007;

23. World Health Organisation (WHO). Guidelines for ATC classification and DDD assigment 2013, 16th ed. Olso, Norway: Collaborating Centre for Drug Statistics Methodology. 2013;

24. Kant, S., Pandaw, C. S., \& Nath, L. M. A management technique for effective management of medical store in hospitals. Medical store management technique. J Acad Hosp Adm.

25. Kementerian Kesehatan Republik Indonesia. Pedoman Penerapan Fomularium Nasional 2014;1-3.

26. Iqbal, M. J., Geer, M. I., \& Dar, P. A. Medicines management in hospitals: a supply chain perspective. Sys Rev Pharm.

27. Kementerian Kesehatan Republik Indonesia. Peraturan Menteri Kesehatan Nomor 72 Tahun 2016 tentang Standar Pelayanan Kefarmasian di Rumah Sakit. Jakarta: Kementerian Kesehatan RI. 2016;

28. Berhe, Y. H., Amaha, N. D., \& Ghebrenegus, A. S. Evaluation of ceftriaxone use in the medical ward of Halibet National Referral and teaching hospital in 2017 in Asmara, Eritrea: a cross sectional restrospective study. BMC Infect diseasses [Internet]. 2019;19(1):465. Available from: https://doi.org/10.1186/s12879-019-4087-z

29. Tortora, G., Funke, B., \& Case, C. Antimicrobial drugs. In Microbiology: an introduction United States: Pearson Education, Inc. Microbiol an Introd. 2019;(558-574).

30. Shalviri, G., Yousefian, S., \& Gholami, K. Adverse events induced by ceftriaxone: a 10-year review of reported cases to Iranian Pharmacovigilance Centre. J Clin Pharm Ther. 2012;37(4):448-51.

31. Yao, Y., Zhou, R., \& Wang, Y. Fatal adverse effects of injected ceftriaxone sodium in China. Pharmacoepidemiol Drug Saf [Internet]. 2012;21(11):1197-1201. Available from: https://doi.org/10.1002/pds.3232

32. Zerr, D. M., Miles-Jay, A., Kronman, M. P., Zhou, C., Adler, A. L., Haaland, W., Weissman, S. J., Elward, A., Newland, J. G., Zaoutis, T., \& Qin, X. Previous Antibiotic Exposure Increases Risk of Infection with Extended-Spectrum- $\beta$-Lactamase- and AmpC-Producing Escherichia coli and Klebsiella pneumoniae in Pediatric Patients. Antimicrob Agents Chemother [Internet]. 2016;60(7):4237-4243. Available from: https://doi.org/10.1128/AAC.00187-16

33. Papp-Wallace, K. M., Endimiani, A., Taracila, M. A., \& Bonomo, R. A. Carbapenems: past, present, and future. Antimicrob Agents Chemother [Internet]. 2011;55(11):4943-4960. Available from: https://doi.org/10.1128/AAC.00296-11

34. El-Gamal, M. I., Brahim, I., Hisham, N., Aladdin, R., Mohammed, H., \& Bahaaeldin A. Recent updates of carbapenem antibiotics. Eur J Med Chem [Internet]. 2017;131:185-95. Available from: https://doi.org/10.1016/j.ejmech.2017.03.022 